\title{
DIAGNOSTIC AND PROGNOSTIC MARKERS OF PERIODONTAL DISEASE
}

\section{Nada Risteska, Bojan Poposki, Kiro Ivanovski, Katarina Dirjanska, Stevica Ristoska, Mirko Saveski}

Ss. Cyril and Methodius University in Skopje, Faculty of Dentistry - Skopje, Department of Oral and Periodontal Diseases, Skopje, N. Macedonia

Corresponding author: Nada Risteska, Ss. Cyril and Methodius University in Skopje, Faculty of Dentistry - Skopje, Department of Oral and Periodontal Diseases, Skopje, N. Macedonia, e-mail: nade_spirovska@yahoo.com

\section{ABSTRACT}

Aim of the study: The aim of this study is to determine the values of salivary enzyme biomarkers (alkaline phosphatase - ALP, aspartate aminotransferase - AST and lactate dehydrogenase - LDH) in subjects with healthy and diseased periodontium and to investigate the possibility of using these salivary enzymes as diagnostic and prognostic markers.

Methods: We collected saliva with the spitting method from all examinees in the morning, using the recommendations provided by Navazesh. The values of the enzymes in saliva were determined spectrophotometrically, with the following methods: ALP-IFCC, AST-IFCC, LDH-PYRUVATE. IGI Silness-Löe was used to determine the presence of gingival inflammation, and to determine the presence of clinically manifest periodontitis, we determined the clinical loss of periodontal attachment with a graduated periodontal probe. For statistical purposes, we used the method of ANOVA Chi Square and Student's t-test.

Results: The difference in the average salivary AST and LDH values between the first and the second group, as well between the first and third group is statistically significant $(p<0.000)$. The difference in the average salivary AST and LDH values between the examinees with gingivitis and the examinees with clinically manifest periodontal disease is statistically insignificant $(p<0.485101$ for AST, $p<0.816665$ for $\mathrm{LDH}$ ). The difference in the average salivary levels of ALP between the three groups is statistically significant $(\mathrm{p}<0.000)$.

Conclusion: The salivary levels of AST, LDH, and ALP can be used as diagnostic markers, while ALP can also be used as a prognostic marker for periodontal disease.

Keywords: periodontal disease, saliva, aspartate aminotransferase, lactate dehydrogenase, alkaline phosphatase

\section{INTRODUCTION}

Periodontal disease is a chronic inflammatory disease of the supporting apparatus of the tooth, which is caused by persistent bacterial infection, and the active inflammatory process leads to the destruction of periodontal tissues. The symptomatology of the disease is completely insignificant, which is why patients with this disease call a dentist when it is already late for 
treatment. Therefore, it is necessary to detect periodontal disease at its early stage using easy, reliable and easily accessible diagnostic tools.

In routine practice, as recommended by Salvi and Lindhe [1], diagnostic procedures such as: clinical measurements (measurement of periodontal pocket depth, determination of bleeding on probing and measurement of clinical loss of periodontal attachment) and radiography are used. These traditional diagnostic procedures are time consuming, but in addition the information they provide is limited, because they are indicators of the activity of the disease in the past, and indicate little of the inflammatory-destructive processes of periodontal disease at the time of their determination. Another disadvantage is that they do not determine the prognosis of the disease in the future, especially in at-risk individuals.

Saliva is an optimal biological fluid, which can be used as a diagnostic tool in periodontal disease. Saliva collection is a simple, non-invasive and safe method [2, 3, 4]. A number of promising salivary biomarkers have been identified that correlate with the clinical parameters of periodontitis. Such are the various salivary proteins, metabolites, and enzymes produced by the host or by periodontal pathogenic bacteria. Several enzymes in saliva have been used for the early diagnosis of periodontitis, including aspartate aminotransferase (AST), alanine aminotransferase (ALT), lactate dehydrogenase (LDH), alkaline phosphatase (ALP), and acid phosphate (ACP). ALP is an enzyme that plays a particularly important role in alveolar bone metabolism, but is also important for the biological turnover of the periodontal ligament and cementum. Malhotra et al. [5] found that total ALP enzyme activity was significantly higher in subjects with periodontal disease than in those with gingivitis or healthy gingiva [5]. According to Oringer et al. [6] AST is an enzyme released by necrotic cells and its increase is associated with the destruction of periodontal tissues. Totan et al. [7] indicate that during periodontal destruction, the amount of AST and ALP in saliva increases. The results of Todorovic et al. [8], obtained in a study conducted on 30 examinees, aged 25-50 years with gingivitis and periodontitis, are similar. They confirm that there is a statistically significant increase in AST, ALT, LDH, creatine kinase (CK), ALP, ACP (acid phosphatase), and gamma glutamyl transferase (GGT), in subjects with periodontal disease compared with subjects in the control group.

An association between smoking, periodontal destruction, and increased ACP, AST, and LDH has also been confirmed [9]. In addition to increased values of ALP, LDH, AST and ALT, periodontal disease is associated with increased values of matrix metalloproteinases $[10,11,12,13,14$, $15,16]$. The previous findings are followed by the data that show that after scaling and root planing the periodontal pockets, there is a decrease in serum and salivary levels of ALP and ACP [17]. Elevated levels of LDH and beta-glucuronidase have been shown in smokers and non-smokers with periodontal disease [18]. Luke et al. [19] confirm that salivary enzyme activity can be used as a biomarker to determine periodontal tissue damage, which may be useful in the diagnosis, prognosis, and evaluation of post-therapeutic effects in periodontal disease.

The aim of the paper was to determine the values of salivary enzyme biomarkers (alkaline phosphatase - ALP, aspartate aminotransferase AST and lactate dehydrogenase - LDH) in subjects with healthy and diseased periodontium and to investigate the possibility of using these salivary enzymes as diagnostic and prognostic markers.

\section{MATERIALS AND METHODS}

The research conducted at the Clinic for Oral and Periodontal Diseases at the USCC "St. Pantelejmon" included 45 examinees, aged 19 to 70 years. The subjects included in the study were randomly selected from individuals coming to the Clinic for Oral and Periodontal Diseases. The criterion for inclusion in the examination is that individuals have at least 20 remaining teeth in their mouth. Those examinees who had diseases (diabetes, blood disorders) which could affect the results of the study, were excluded. The subjects were divided into three groups: the first group consisted of 15 subjects with clinically healthy gingiva, the second group consisted of 15 subjects with gingivitis, and the third group consisted of 15 subjects with clinically manifest periodontitis. The criterion for inclusion of the subjects in the third group (subjects with clinically manifest periodontitis), was the presence of attachment loss of 4 or more millimeters on at least two surfaces of the tooth, on at least two teeth in the patient's mouth.

The test required saliva obtained from the subjects, spectrophotometer, pipettes, water bath, reagents, refrigerator, test tubes, and disposable plastic laboratory cups.

We collected saliva with the spitting method, using the recommendations provided by Navazesh [20], from all examinees in the morn- 
ing. After processing the saliva, it was frozen at $-20^{\circ} \mathrm{C}$ in a refrigerated chamber.

The values of the enzymes in the saliva were determined spectrophotometrically at the biochemical laboratory of the Department of Oral and Periodontal Diseases with the following methods: ALP-IFCC [21], AST-IFCC [22], LDH-PYRUVATE [23].

After saliva collection, all subjects underwent a periodontal examination to determine the condition of the periodontium. IGI Silness-Löe was used to determine the presence of gingival inflammation, and to determine the presence of clinically manifest periodontitis, we determined the clinical loss of periodontal attachment with a graduated periodontal probe. Based on the periodontal examination, we grouped the examinees into the above three groups: healthy subjects, subjects with gingivitis, and subjects with manifest periodontal disease.

We statistically processed the obtained results, and determined the significance of the differences between the groups using the method of ANOVA Chi Sqr and Student's t-test.

\section{RESULTS}

The results of this research are presented in a table.

Table 1 shows the distribution of examinees by gender and age. In the first group there are
7 male and 8 female examinees, in the second, 9 male and 6 female examinees, and in the third, 7 male and 8 female examinees. The average age for the first group is 24.8 , for the second 30.4 , and for the third 56.1 years. According to ANOVA Chi Sqr, we registered a significant difference between the ages of the three examined groups.

Table 2 shows the mean values and differences between the mean AST values between the three groups. The average value of AST in the first group is $9,020 \mathrm{U} / \mathrm{L}$, in the second group 23,373 $\mathrm{U} / \mathrm{L}$, and in the third group 24,173 U/L. According to the Student t-test, the differences in the mean values of AST between the first and second group, as well as between the first and third group are statistically significant for $p<0.000$. The difference between the mean value of AST in subjects with gingivitis and subjects with periodontitis was statistically insignificant, $\mathrm{p}<0.485101$.

Table 3 shows the mean values and the differences between the mean LDH values between the three groups. The average LDH value in the first group is 28,593, in the second group 156,506, and in the third group 160,273. According to the Student t-test, the differences in the average LDH values between the first and second group, as well as between the first and third group are statistically significant, $p<0.000$. The difference between the mean LDH in subjects with gingivitis and those with periodontitis was statistically insignificant, $p$ $<0.816665$.

Table 4 shows the values and differences between the ALP values between the three groups.

Table 1. Distribution of examinees by gender and age

\begin{tabular}{|l|l|l|l|}
\hline & group I & group II & group III \\
\hline sex & $\begin{array}{l}\text { male }-7 \\
\text { female }-8\end{array}$ & $\begin{array}{l}\text { male }-9 \\
\text { female }-6\end{array}$ & $\begin{array}{l}\text { male }-7 \\
\text { female }-8\end{array}$ \\
\hline age/years & 24.8 & 30.4 & 56.1 \\
\hline
\end{tabular}

Legend: group I - examinees with a healthy periodontium; group II - examinees with gingivitis; group III examinees with periodontitis.

Table 2. Average salivary values of AST in the three groups of examinees

\begin{tabular}{|l|l|l|l|l|}
\hline \multicolumn{1}{|c|}{ AST U/L } & \multicolumn{1}{|c|}{ Rank-sum } & \multicolumn{1}{c|}{ Rank-sum } & \multicolumn{1}{c|}{ t-value } & \multicolumn{1}{c|}{$\mathrm{p}$} \\
\hline $\begin{array}{l}\text { between group I and } \\
\text { group II }\end{array}$ & 9.020 & 23.373 & 16.0987 & 0.000000 \\
\hline $\begin{array}{l}\text { between group I and } \\
\text { group III }\end{array}$ & 9.020 & 24.173 & 16.663 & 0.000000 \\
\hline $\begin{array}{l}\text { between group II } \\
\text { and group III }\end{array}$ & 23.373 & 24.173 & 0.707 & 0.485101 \\
\hline
\end{tabular}

Legend: group I - examinees with a healthy periodontium; group II - examinees with gingivitis; group III examinees with periodontitis 
The amount of ALP in the first group is 10,433, in the second group 21,466, and in the third group 44,893 . According to the Student t-test, the differences in the mean ALP values between all three groups are statistically significant with $\mathrm{p}<0.000$.

\section{DISCUSSION}

There are many benefits to using saliva as a biological fluid. Saliva collection is easy, cheap, fast and non-invasive. In addition, saliva as a "mirror of the human body" can reflect the physiological and pathological condition of the body [24]. A biomarker is a biological factor for normal or pathogenic processes. The identification of biomarkers is useful for the prevention, diagnosis and prognosis of diseases, as well as for monitoring the progression of pathological disorders. Various molecules present in biological fluids can serve as biomarkers, such as DNA, coding and non-coding RNA, lipids, metabolites, proteins, and even some microbes. It is in this context that saliva stands out as a useful diagnostic tool in the detection of biomarkers [25]. Inflammatory processes characteristic of periodontal disease are associated with metabolic and biochemical changes in periodontal tissues. They occur as a result of the interaction between dental plaque bacteria and host cells [26]. As a consequence of these interactions, periodontal tissues are damaged and various enzymes and inflammatory mediators are released from the host cells themselves. Therefore, one of our goals was to investigate the salivary concentration of enzymes in individuals with healthy and diseased periodontium. The results from this research confirmed the findings of a close relationship between periodontal tissue destruction and increased levels of AST, ALP and LDH in saliva.

The average age for subjects with clinically healthy gingiva is 24.8 , for subjects with gingivitis 30.4 , and for subjects with clinically manifest periodontitis is 56.1 years. According to ANOVA Chi Sqr, we registered a significant difference between the ages of the three examined groups (Table 1). This result confirms the fact that periodontitis is characteristic of individuals in advanced age.

The results from our research showed a statistically significant increase in the AST concentration in saliva in examinees with gingivitis and periodontitis, compared with examinees with a healthy periodontium (Table 2). The difference between the values of AST in the examinees with gingivitis and periodontitis is statistically insignificant. Our results are in line with the results of Luke et al. [19], who also found significantly higher mean AST salivary values in subjects with periodontitis compared with the control group. We consider that significantly higher AST values in periodontitis subjects compared to healthy subjects are due to the fact that AST is

Table 3. Average salivary LDH values in the three groups of examinees

\begin{tabular}{|l|l|l|l|l|}
\hline \multicolumn{1}{|c|}{ LDH U/L } & Rank Sum & \multicolumn{1}{c|}{ Rank Sum } & \multicolumn{1}{c|}{ t-value } & \multicolumn{1}{c|}{ P } \\
\hline between group I and group II & 28.593 & 156.506 & 11.585 & 0.000000 \\
\hline between group I and group III & 28.593 & 160.273 & 10.612 & 0.000000 \\
\hline $\begin{array}{l}\text { between group II and group } \\
\text { III }\end{array}$ & 156.506 & 160.273 & 0.2340 & 0.816665 \\
\hline
\end{tabular}

Legend: group I - examinees with a healthy periodontium; group II - examinees with gingivitis; group; III subjects with periodontitis

Table 4. Average salivary values of ALP in the three groups of examinees

\begin{tabular}{|l|l|l|l|l|}
\hline \multicolumn{1}{|c|}{ ALP U/L } & \multicolumn{1}{|c|}{ Rank Sum } & \multicolumn{1}{c|}{ Rank Sum } & \multicolumn{1}{c|}{ t-value } & \multicolumn{1}{c|}{ P } \\
\hline $\begin{array}{l}\text { between group I and group } \\
\text { II }\end{array}$ & 10.433 & 21.466 & 8.357 & 0.000000 \\
\hline $\begin{array}{l}\text { between group I and group } \\
\text { III }\end{array}$ & 10.433 & 44.893 & 16.920 & 0.000000 \\
\hline $\begin{array}{l}\text { between group II and group } \\
\text { III }\end{array}$ & 21.466 & 44.893 & 10.927 & 0.000000 \\
\hline
\end{tabular}

Legend: group I - examinees with a healthy periodontium; group II - examinees with gingivitis; group III examinees with periodontitis 
an enzyme found in the cytoplasm of cells and is released during cell death, which occurs during active destruction of periodontal tissue.

The results obtained from our research for the salivary concentrations of LDH, were similar to those of AST, which can be seen in Table 3. The values of this enzyme are significantly higher in individuals with periodontal disease, compared to individuals who have a healthy periodontium. Our results are in line with Haghgoo et al. [27, 28, 29, 30, 31, 32], who demonstrated statistically significant higher levels of LDH in saliva in subjects with periodontal disease than in subjects with clinically healthy gingiva. LDH is an intracellular enzyme found in almost every cell in the human body. This enzyme plays an important role in creating the energy needed for the body to function. When tissue is damaged for any reason, $\mathrm{LDH}$ is released into the bloodstream or other body fluids, including saliva [33, $34,35,36]$. Because of this, we believe that the significantly increased LDH values in our subjects with clinically manifest periodontitis are due to the release of this enzyme as a result of disruption of the integrity of periodontal tissues, which occurs during inflammatory changes in these tissues.

Table 4 shows the average salivary ALP values of the three groups of examinees and the differences between those values. It can be noted that the differences in the mean ALP values between the three groups are statistically significant. The results obtained are consistent with the results obtained by Totan et al. [7], whose findings confirm significantly higher ALP values in subjects with periodontitis, compared with subjects in the control group. Increased salivary ALP values in periodontitis subjects are associated with alveolar bone resorption, which is actually one of the main features of periodontal disease.

\section{CONCLUSION}

1. The increased concentrations of AST and $\mathrm{LDH}$ in saliva in patients with gingivitis and periodontitis are the result of their release when the periodontal tissue cells are affected by inflammation.

2. Elevated ALP levels in saliva are the result of destruction of alveolar bone and damage to osteoblast and fibroblast membranes.
3. Salivary concentrations of AST and LDH can serve as diagnostic markers, while ALP concentrations in addition to being a diagnostic marker can also be a prognostic marker of periodontal disease.

\section{REFERENCES}

1. Lindhe $\mathrm{J}$ i suradnici. Klinička parodontologija $\mathrm{i}$ dentalna implantologija I-II. Prema 5. engleskom izdanju. Nakladni zavod Globus, 2010: 434.

2. Nunes LAS, Brenzikofer R, Macedo DV. Reference intervals for saliva analytes collected by a standardized method in a physically active population. Clin Biochem 2011; 44:1440-4.

3. Jingyi L, Yixiang D. Saliva: A potential media for disease diagnostics and monitoring. Oral Oncol 2012; 48:569-77.

4. Tabak LA. A revolution in biomedical assessment: the development of salivary diagnostics. J Dent Educ 2001; 65:1335-9.

5. Malhotra R, Grover V, Kapoor A et al. Alkaline phosphatase as a periodontal disease marker. Indian J Dent Res, Oct-Dec 2010; 21(4):531-6.

6. Oringer R J, Howell T H, Nevins M L et al. Relationship between crevicular aspartate aminotransferase levels and periodontal disease progression. J Periodontol 2001 Jan; 72(1):17-24.

7. Totan A, Greabu M, Totan C et al. Salivary aspartate aminotransferase, alanine aminotransferase and alkaline phosphatase: possible markers in periodontal diseases. Clin Chem Lab Med 2006; 44(5): 612-5.

8. Todorovic T, Dozic I, Vicente-Barrero $\mathrm{M}$ et al. Salivary enzymes and periodontal disease. Med Oral Patol Oral Cir Bucal 2006 Mar 1; 11(2): E115-9.

9. Abhilasha Patil S, V Ranganath, Naresh Kumar $\mathrm{C}$ et al. Evaluation of salivary biomarkers of periodontitis among smokers and non-smokers: A novel study. J Family Med Prim Care 2020 Feb 28;9 (2): 1136-1142.

10. Costa P.P., Trevisan G.L., Macedo G.O. et al. Salivary Interleukin-6, Matrix Metalloproteinase-8, and Osteoprotegerin in Patients with Periodontitis and Diabetes. J. Periodontol 2010;81:384391.

11. Miricescu D., Totan A., Calenic B. et al. Salivary biomarkers: Relationship between oxidative stress and alveolar bone loss in chronic periodontitis. Acta Odontol Scand 2013;72:42-47.

12. Zappacosta B., Manni A., Persichilli S. et al. Salivary thiols and enzyme markers of cell damage in periodontal disease. Clin Biochem 2007;40:661-665. 
13. Kugahara T., Shosenji Y., Ohashi K. Screening for periodontitis in pregnant women with salivary enzymes. J. Obstet Gynaecol Res 2007;34:40-46.

14. Luke R., Khan S.N., Iqbal P.S. et al. Estimation of Specific Salivary Enzymatic Biomarkers in Individuals with Gingivitis and Chronic Periodontitis: A Clinical and Biochemical Study J Int Oral Health 2015;7:54-57.

15. Dabra S., China K., Kaushik A. Salivary enzymes as diagnostic markers for detection of gingival/periodontal disease and their correlation with the severity of the disease. J Indian Soc Periodontol 2012;16:358-364.

16. Nomura Y., Tamaki Y., Tanaka T. et al. Screening of periodontitis with salivary enzyme tests. J Oral Sci 2006;48:177-183.

17. Koppolu P, Sirisha S, Mishra A et al. Alkaline phosphatase and acid phosphatase levels in saliva and serum of patients with healthy periodontium, gingivitis, and periodontitis before and after scaling with root planing: A clinico-biochemical study. Saudi J Biol Sci 2021 Jan;28(1):380-385.

18. Syed A, Ravi L, Tirth A et al. Lactate Dehydrogenase and $\beta$-Glucuronidase as Salivary Biochemical Markers of Periodontitis Among Smokers and Non-Smokers. Sultan Qaboos Univ Med J 2018 Aug;18(3): e318-e323.

19. Luke R, Khan N, Iqbal S et al. Estimation of Specific Salivary Enzymatic Biomarkers in Individuals with Gingivitis and Chronic Periodontitis: A Clinical and Biochemical Study. J Int Oral Health 2015 Sep;7(9):54-7.

20. Navazesh. M, Christensen C.M. A Comparison of Whole Mouth Resting and Stimulated Salivary Measurement Procedures. Journal of Dental Research, 1982; 61(10):1158-62

21. Young DS. Effects of drugs on clinical laboratory tests, 5th ed. AACC Press, 2000.

22. Gella FJ, Olivella T, Cruz Pastor M. et al. A simple procedure for routine determination of aspartate aminotransferase and alanine aminotransferase with pyridoxal phosphate. Clin Chim Acta 1985; 153: 241-247.

23. Lorentz K, Klauke R, Schimidt E. Recommendation for the determination of the catalytic concentration of lactate dehydrogenase at $37^{\circ} \mathrm{C}$. Eur J Clin Chem Clin Biochem 1993;31:897- 899.

24. Kaczor-Urbanowicz KE, Carreras-Presas CM, Aro K et al. Saliva diagnostics - Current views and directions. Exp Biol Med (Maywood) 2017 Mar;242(5):459-472.

25. Buzalaf MAR, Ortiz AC, Carvalho TS. et al. Saliva as a diagnostic tool for dental caries, peri- odontal disease and cancer: is there a need for more biomarkers. Expert Rev Mol Diagn 2020 May;20(5):543-555.

26. Tsuchida S, Satoh M, Takiwaki M. et al.Current Status of Proteomic Technologies for Discovering and Identifying Gingival Crevicular Fluid Biomarkers for Periodontal Disease. Int J Mol Sci 2018 Dec 26;20(1):86.

27. Haghgoo JM, Soheilifar S, Bidgoli M. et al. Comparison of Whole Salivary Lactate Dehydrogenase Level in Patients With and Without Periodontal Disease. Avicenna J Dent Res 2016;8(4): 5.

28. Miyoshi N, Tanigawa T, Nishioka S et al. Association of salivary lactate dehydrogenase level with systemic inflammation in a Japanese population. J Periodontal Res 2018 Aug;53(4):487494

29. Nomura Y, Tamaki Y, Tanaka T, et al. Screening of periodontitis with salivary enzyme tests. J Oral Sci 2006;48:177-183.

30. De La Peña VA, Diz Dios P, Tojo Sierra R. Relationship between lactate dehydrogenase activity in saliva and oral health status. Arch Oral Biol 2007;52:911-915

31. Segal A, Wong DT. Salivary diagnostics: enhancing disease detection and making medicine better. Eur J Dent Educ. 2008;12: 22-29

32. Nomura Y, Okada A, Kakuta E, et al. A new screening method for periodontitis: an alternative to the community periodontal index BMC Oral Health. 2016;16:64

33. Lamster IB, Mandella RD, Gordon JM. Lactate dehydrogenase activity in gingival crevicular fluid collected with filter paper strips: analysis in subjects with non-inflamed and mildly inflamed gingiva. J Clin Periodontol 1985;12:153-61

34. Lamster IB, Vogel RI, Hartley LJ, et al. Lactate dehydrogenase, beta-glucuronidase and arylsulfatase activity in gingival crevicular fluid associated with experimental gingivitis in man. J Periodontol 1985;56:139-47

35. Rygh P. Ultrastructural changes in tension zones of rat molar periodontium incident to orthodontic tooth movement. Am J Orthod 1976;70:269-81

36. Atici K, Yamalik N, Eratalay K, et al. Analysis of gingival crevicular fluid intracytoplasmic enzyme activity in patients with adult periodontitis and rapidly progressive periodontitis: a longitudinal study model with periodontal treatment. J Periodontol 1998;69:1155-63. 


\title{
Резиме
}

\section{ДИЈАГНОСТИЧКИ И ПРОГНОСТИЧКИ МАРКЕРИ НА ПАРОДОНТАЛНАТА БОЛЕСТ}

\author{
Нада Ристеска, Бојан Попоски, Ќиро Ивановски, \\ Катарина Дирјанска, Стевица Ристоска, Мирко Савески
}

Оддел за орални и пародонтални заболувања, Стоматолошки факултет, Универзитет „Св. Кирил и Методиј“, Скопје, РС Македонија

Цел на трудот: Целта на овој труд е да се одредат вредностите на саливарните ензимски биомаркери (алкална фосфатаза - ALP, аспартат аминотрансфераза - AST и лактат дехидрогеназа - LDH) кај испитаници со здрав и заболен пародонт и да се испита можноста за користење на овие саливарни ензими како дијагностички и прогностички маркери.

Методи: Кај сите испитаници колекциониравме плунка со спитинг методата, во утринските часови, според препораките на Navazesh. Вредностите на ензимите во плунката ги определувавме спектрофотометриски, со следните методи: ALP-IFCC, AST-IFCC, LDH-PYRUVATE. За утврдување на присуството на гингивална имфламација беше користен ИГИ Silness-Löe, а за утврдување присуство на клинички манифестна пародонтопатија со градуирана пародонтална сонда го определувавме клиничкото губење на пародонталниот припој. За статистички цели ги употребивме методите на ANOVA Chi Square и Student-овиот t-тест.

Резултати: Разликата во просечните саливарни вредности на AST и LDH меѓу првата и втората група, како и меѓу првата и третата група е статистички значајна $(\mathrm{p}<0.000)$. Разликата меѓу просечните саливарни вредности на AST и ЛДХ кај испитаниците со гингивит и испитаниците со пародонтопатија е статистички незначајна ( $<<0.485101$ за AST и $\mathrm{p}<0.816665$ за LDH). Разликите меѓ п просечните саливарни вредности на ALP меѓу сите три групи се статистички значајни $(\mathrm{p}<0.000)$.

Заклучок: Саливарните вредности на AST, LDH и ALP можат да послужат како дијагностички маркери, додека ALP може да послужи и како прогностички маркер за пародонталната болест.

Клучни зборови: трансплантација на бубрег, протеомика, хронична нефропатија на алографт 
